The Evolution of Current Account Deficits in the Euro Area Periphery and the Baltics: Many Paths to the Same Endpoint

Joong Shik Kang and Jay C. Shambaugh 
IMF Working Paper

Research Department

\title{
The Evolution of Current Account Deficits in the Euro Area Periphery and the Baltics: Many Paths to the Same Endpoint
}

\author{
Prepared by Joong Shik Kang and Jay C. Shambaugh ${ }^{1}$ \\ Authorized for distribution by Hamid Faruqee
}

July 2013

\section{This Working Paper should not be reported as representing the views of the IMF.} The views expressed in this Working Paper are those of the author(s) and do not necessarily represent those of the IMF or IMF policy. Working Papers describe research in progress by the author(s) and are published to elicit comments and to further debate.

\begin{abstract}
Explanations of the large current account deficits for the euro area periphery and the Baltics in the run up to the crisis revolve around two main factors: deteriorating export performance or demand driven booms. We add that there were important movements in transfers and net income balances. While export performance remained relatively stable in most countries, for some countries, when transfers declined, households and firms borrowed so as to maintain the same level of spending. This was part of a persistent failure to adjust to trade deficits, which, along with rising net income payments, led to growing current account deficits. All of these factors played varying roles in the development of current account deficits across these countries.
\end{abstract}

JEL Classification Numbers: F24, F32, F41

Keywords: current account deficit, transfer, income balance, competitiveness, domestic boom Author’s E-Mail Address: jkang@imf.org, jshambaugh@gwu.edu

\footnotetext{
${ }^{1}$ The authors thank Olivier Blanchard for his guidance, Tamim Bayoumi, Jörg Decressin, Gian Maria MilesiFerretti, and Steven Phillips for their valuable comments, and Daniel Rivera-Greenwood for research assistance.
} 


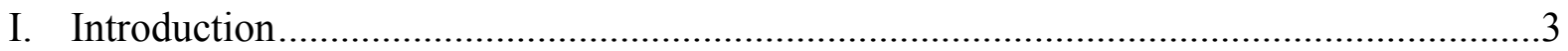

II. Different Paths to External Imbalances ..................................................................6
A. Exports .6

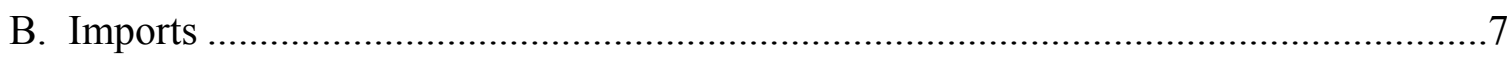

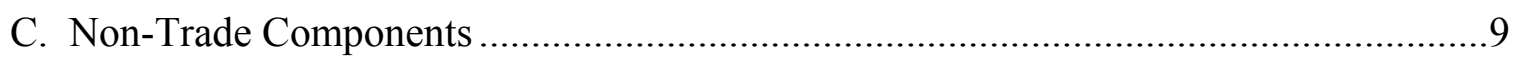

III. Current Account Developments for Individual Countries ...........................................10

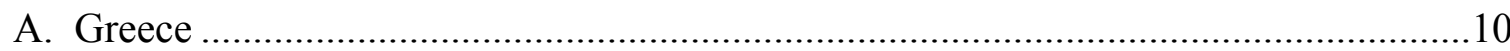

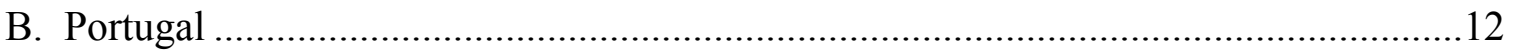

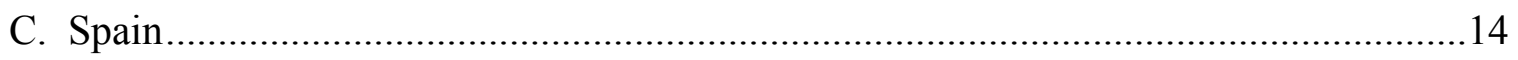

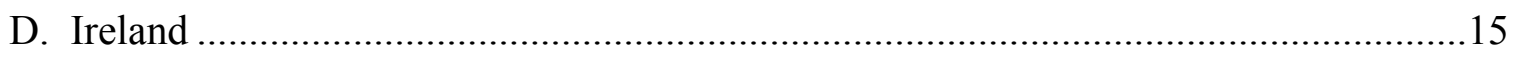

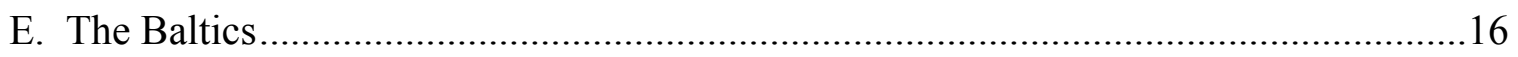

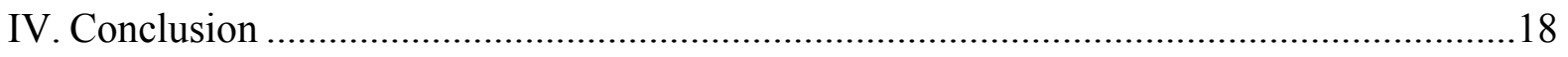

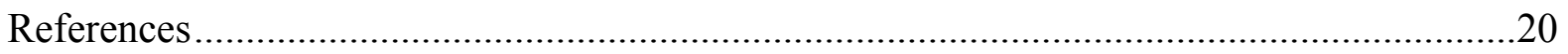

Appendix. Merchandise Export Market Share............................................................21 


\section{INTRODUCTION}

On the eve of the global financial crisis, a number of euro area periphery countries (especially Greece, Ireland, Portugal, and Spain²) along with the Baltic countries faced large and growing current account deficits (Figure 1). This paper untangles some of the different developments across the euro area periphery and the Baltics in the run-up to the crisis, in particular emphasizing the evolution of the non-trade channel, which has received less attention in the literature, and its implication for the current account. Two main explanations for widening current account deficits for many European countries in mid-2000s are: (i) deteriorating export performance due to a steady deterioration of competitiveness and (ii) a domestic demand-driven boom stemming from excessive optimism, capital flow-driven cheap credit, as well as fiscal excess. ${ }^{3}$ Conventional price indicators show deterioration of their competitiveness since the inception of the Euro: there was significant appreciation of the CPI-based REER and unit labor costs (ULCs) in these countries increased sizably relative to other Euro area countries (Figures 2 and 3). ${ }^{4}$ These data are consistent with the view that these countries lost their competitiveness in the global market, which contributed to large current account deficits in the run up to the crisis.
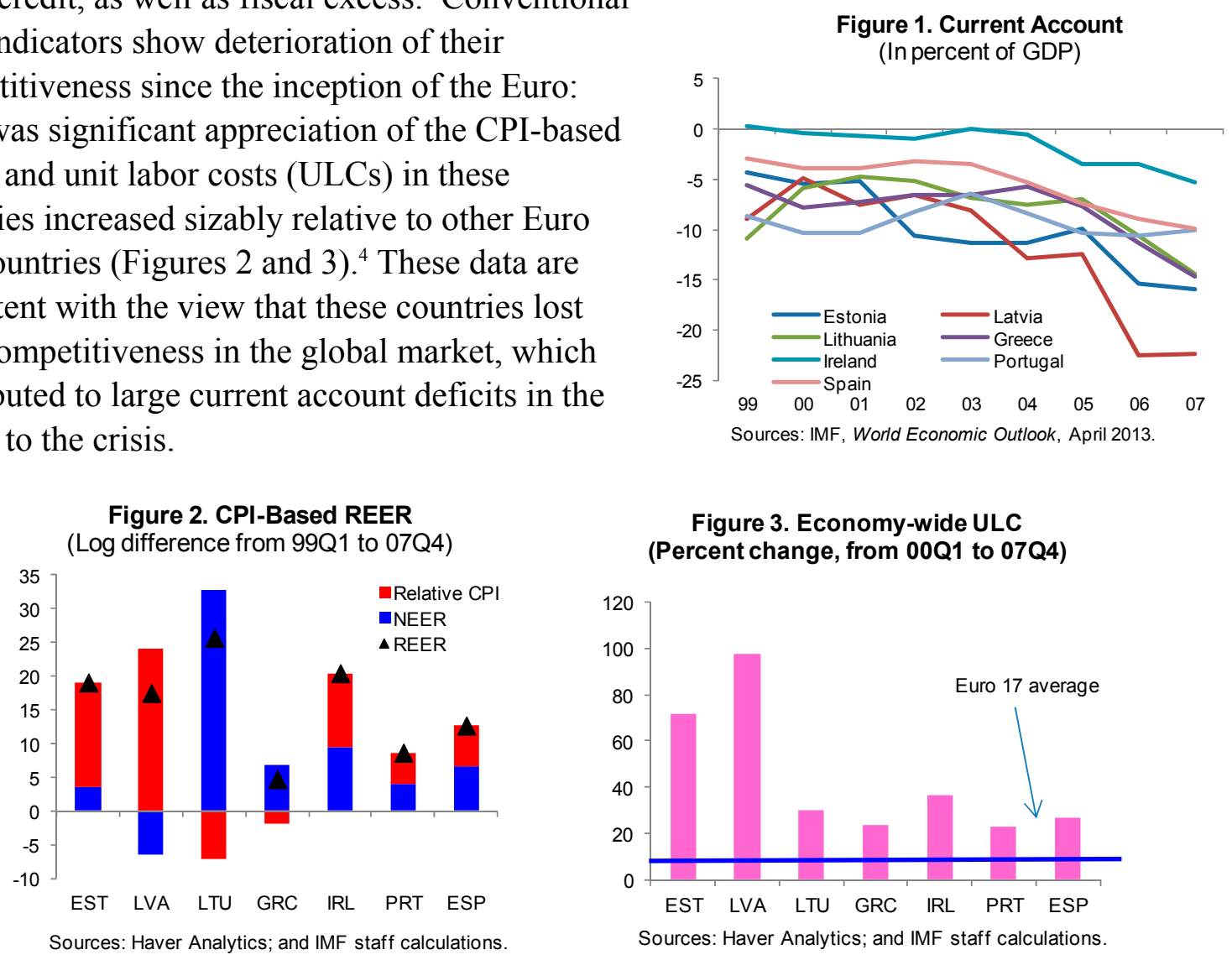

\footnotetext{
${ }^{2}$ This paper will focus on Greece, Ireland, Portugal and Spain as they were the euro countries with the largest current account deficits on the eve of the crisis. Often, Italy is included in the group based on issues with sovereign debt. But, Italy's current account did not move into large deficit prior to the crisis and is thus not as relevant to this discussion.

${ }^{3}$ While domestic demand booms typically lead to some sort of competitiveness loss, the former comes with high output whereas "exogenous" losses in competitiveness (not due to domestic demand boom) come with low output.

${ }^{4}$ Value-added REER (Bems and Johnson, 2012), which conceptually better capture the competitiveness, appreciated more in Estonia and Spain than CPI-based REERs, while appreciated less in Portugal and Greece.
} 
However, several quantity measures indicate that export performance for these economies remained stable during this period. The exports-to-GDP ratio for many of these countries remained relatively stable or increased in the 2000s. The merchandise export market share for these countries declined some in the 1990s, but was flat in the euro era except for Ireland, whose economy was shifting towards a service economy. The Baltics' market share grew throughout (Figure 4). ${ }^{5}$

These patterns hint that other factors may have driven

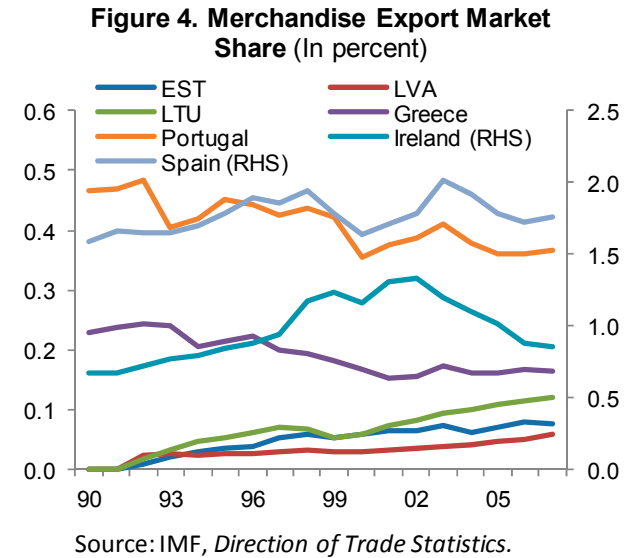
large current account deficits for these economies. The seemingly contradictory pattern between large increases in ULC (economy-wide) and non-deteriorating export sector performance can be partly understood by looking at ULC for tradable and non-tradable sectors separately. There was a limited increase in tradable sector ULC, consistent with the export sector maintaining its performance in most of these countries. But, a sizable increase in non-tradable sector ULC led to a large deterioration of economy-wide ULC (Figure 5). ${ }^{6}$ Thus, the trade balance may have deteriorated due to surging imports arising from a domestic demand boom while exports remained strong. In fact, as Figure 6 shows, imports did rise substantially as a share of GDP in the Baltics and to some extent in Spain and Greece. ${ }^{7,8}$

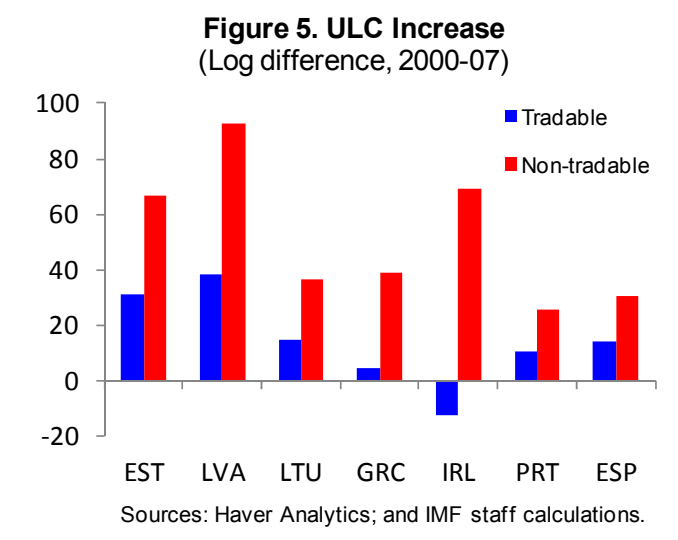

Figure 6. Change in Exports and Imports (In percent of GDP, 1999-2007)

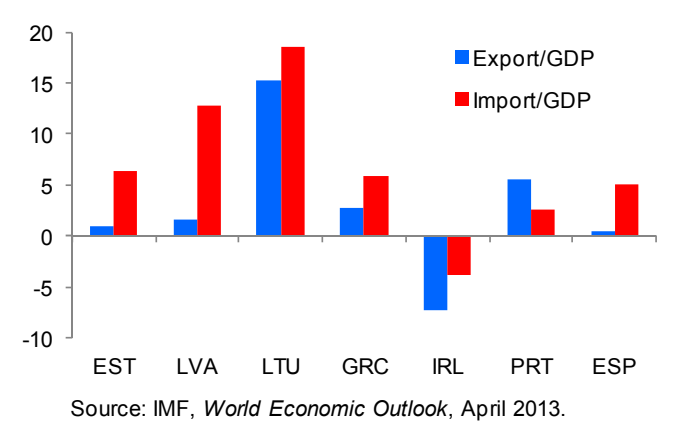

\footnotetext{
${ }_{6}^{5}$ Gaulier and Vicard (2012) also argue that weakening export performance did not generate the imbalances. ${ }^{6}$ Tradable sectors in this paper include 'agriculture, forestry \& fishing', 'industry excluding construction', 'trade, travel, accommodation \& food', 'information \& communication', and 'financial insurance.'

${ }^{7}$ Once again, Ireland is a bit of an outlier. As the non-traded share of its economy was growing rapidly and import content of exports is relatively high, both imports and exports were declining as a share of output.

${ }^{8}$ It still remains a puzzle that those countries with faster increase in tradables sector ULC experienced rising merchandise market shares. Improvement of exporting goods quality could be a factor reconciling these or it may be due to some measurement issue, but further analysis is beyond the scope of this paper.
} 
However, as Figure 7 shows, the current account worsened far more than the trade balance in many of these countries. In fact, Portugal's trade balance improved over this period. Declining transfers and rising net income payments contributed to a worsening current account balance even without much deterioration of the trade balance. This substantial deterioration of non-trade components of the current account has received less attention thus far in the literature than movements in the trade balance. ${ }^{9}$

Figure 7. Current Account Development (In percent of GDP, 1999-2007)

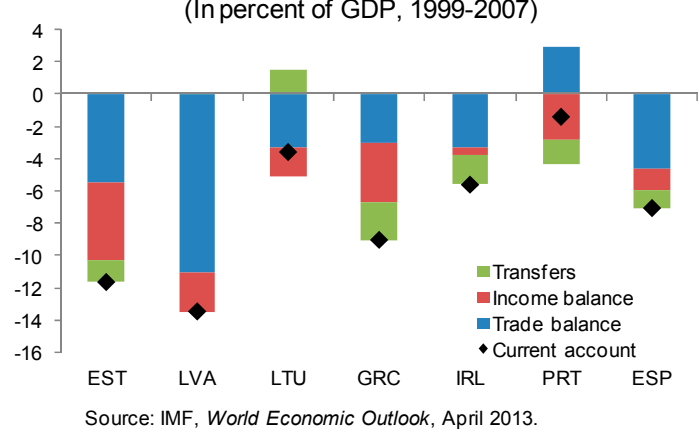

A number of papers have explored the rising deficits in the euro periphery and Baltics. Other papers have often focused on a singular cause. A series of papers examine the export performance of these countries. Chen, Milesi-Ferretti, and Tressel (2012) make an important contribution examining the way in which some of these countries may have been left out of certain parts of the global value chain. They highlight the fact that the peripheral euro countries saw rising imports from emerging Asia, but were not substantial exporters to this region. Berger and Nitsch (2010) focus more on intra-euro area trade and argue that the advent of the euro led to larger imbalances within euro area and greater sensitivity to drivers of imbalances. Bayoumi, Harmsen, and Turunen (2011) also focus on intra-euro trade and note that price elasticities for euro area exports appear to be much higher than non-euro exports. This would suggest that the within euro ULC changes are particularly important to export performance. Similar to this paper, Gaulier and Vicard (2012) argue that export performance does not explain the decline in current accounts broadly and that in addition, declining price competitiveness does not explain any decline in export performance.

Other papers have examined the potential domestic causes. Ivanova (2012) argues that while structural policies receive an extensive amount of attention, they did not evolve in a way consistent with widening global imbalances prior to the crisis. Such factors may help explain some of the long-standing gaps across countries, but not the expansion of deficits over the previous decade. Lane and Pels (2012) provide excellent evidence for one aspect of the rising imports generating rising trade deficits view. They document the way in which rising growth expectations led to rising current account deficits across parts of Europe. Jaumotte and Sodsriwiboon (2010) also focus on imports arguing that falling savings led to the rising deficits, though they do not explore why savings fell (optimism, lending booms, falling transfers, etc). Atoyan, Manning, and Rahman (2013) examined current account developments before and after the crisis by focusing on sectoral savings and investment, and found important cross-country differences. Bakker and Klingen (2012) contains an extensive

\footnotetext{
${ }^{9}$ Holinski et al (2012) also notes the importance of changes in transfers and net income.
} 
country-by-country analysis of the demand boom in the run-up to the crisis, including the effects of competitiveness and the role of fiscal policy.

This paper contributes to this literature by trying to untangle some of the different developments across the euro area periphery and the Baltics in the run-up to the crisis. This assessment of the cause of external imbalances will help us to understand what has to be repaired or changed in these economies to recover the external balances going forward. Kang and Shambaugh (2013) provides more detailed discussion on the need for internal devaluation for these countries, the progress that so far has been made, and the link between the different paths to the imbalances and the adjustment path. We start by briefly reviewing several factors that can cause large current account deficits together with their different implications for other macroeconomic indicators.

\section{Different PATHS to External ImbalanceS}

The current account can deteriorate for many reasons. Export performance can deteriorate due to rising ULCs or global competitiveness factors. Domestic demand-driven booms, due to excessive optimism, cheap credit from capital inflows, or fiscal excess, can also lead to a surge in imports. Or, the current account could be moving for reasons beyond trade: changes in transfers or net income payments. While all of these factors lead to large current account deficits, they differ widely in their predictions for domestic growth, export performance, and other macroeconomic indicators.

\section{A. Exports}

Higher wage growth relative to productivity growth in the export sector leads to a loss of price competitiveness in global markets. In this case, we can observe deterioration of price competitive indicators such as rising ULC in the tradable sector and an appreciation of the REER. On quantity, export volume (or export-toGDP ratio) can decline, leading to a smaller contribution to economic growth and a decline in the global market share. Figure 8 shows the experience of Estonia. After rapid export growth from 2002 to 2005 , ULC in the tradable sector began to rise very quickly from 2005 to 2007 . As these costs increased, export growth slowed notably. Again, though, as seen in Figure 5, there has been little increase in tradable sector ULC outside of Estonia and Latvia.

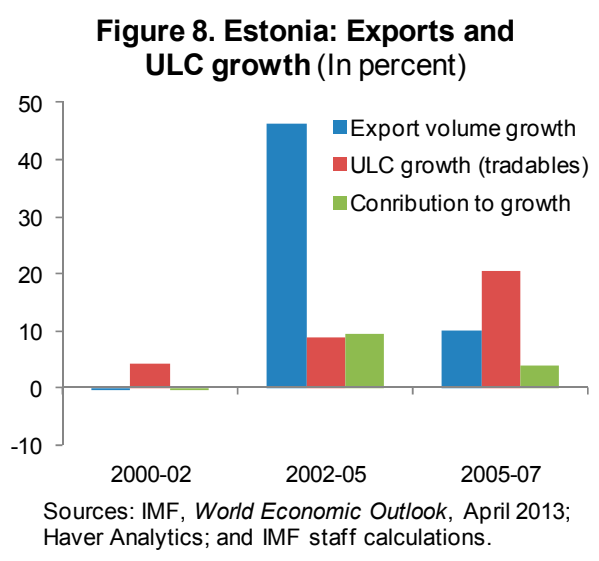

Export performance can also weaken due to composition effects. Even when wages grow in line with productivity growth, a country could lose niche markets if they cannot move up the value chain while their trading partners increase the quality of export goods. In this case, 
weak export performance is captured by quantity measures, while price measures may not capture this type of competitiveness problems (see Chen, Milesi-Ferretti, and Tressel, 2012).

As noted above, the export performance of these economies did not appear to suffer on broad metrics during the 1999-2007 period. Export-to-GDP ratios were rising and market sharesafter falling during the $1990 \mathrm{~s}$ - appeared to stabilize during this period. One may worry that a declining competitiveness was masked by the pro-trade impact of the introduction of the euro, but these countries broadly maintained their market share in non-euro export markets. ${ }^{10}$ As Table 1 shows, Spain and the Baltics increased their non-euro export market share over the period and Greece largely held constant. Portugal did see a decline, but the full decline was from 1999 to 2000. After that, the market share was stable. As before, Ireland lost market share in merchandise trade as part of a shift over towards a more services-intensive economy. ${ }^{11}$ In addition, Gaulier and Vicard (2012) estimate export performance controlling for geographical and sectoral effects. They, too, find that there is no export performance decline. They do see sectoral impacts on Portugal, suggesting that the decline seen in Portugal's export share is connected to its position in global value chains (perhaps consistent with the second story of export decline.)

Table 1. Market Share of Merchandise Exports (ex-Euro Area)

\begin{tabular}{lcccc} 
Country & 1999 & 2000 & 2007 & $\%$ change $99-07$ \\
\hline Greece & $0.13 \%$ & $0.14 \%$ & $0.13 \%$ & $-2 \%$ \\
Ireland & $1.05 \%$ & $1.00 \%$ & $0.70 \%$ & $-33 \%$ \\
Portugal & $0.19 \%$ & $0.17 \%$ & $0.17 \%$ & $-12 \%$ \\
Spain & $0.99 \%$ & $0.93 \%$ & $1.06 \%$ & $7 \%$ \\
Estonia & $0.05 \%$ & $0.04 \%$ & $0.07 \%$ & $55 \%$ \\
Latvia & $0.03 \%$ & $0.02 \%$ & $0.05 \%$ & $90 \%$ \\
Lithuania & $0.05 \%$ & $0.05 \%$ & $0.12 \%$ & $150 \%$ \\
\hline
\end{tabular}

Sources: IMF, Direction of Trade Statistics; and IMF staff estimates.

\section{B. Imports}

A domestic boom due to capital inflows and low interest rates can lead to a surge in imports. Especially following financial opening, financial intermediaries may find more opportunities, and they expand the supply of funds. This surge in capital inflows allows households and businesses to access funds at much lower interest rates, leading to a lending boom and a strong pick up in consumption and investment, including the housing sector, and corresponding increase in imports. In this case, ULC would increase, in particular in the non-

\footnotetext{
${ }^{10}$ See table in Appendix for detailed information on the evolution of merchandise export market share of these countries in various regions. Given the rapid growth among some other exporters around the world, it would not have been a surprise to see a small share decline, but these countries broadly maintained their market shares.

${ }^{11}$ Nkusu (2013) noted that Ireland's service market share increased in 2000s.
} 
tradable sector, and output will also increase. This process can also potentially lead to a housing market bubble. The experience of Latvia in the 2000s shows a dramatic increase in capital inflows, followed closely by sharply rising ULCs (Figure 9). Figure 10 also shows the rapid house price increases seen in Ireland, Spain and Greece. The drastic increases of the ULC in the non-tradable sector in these countries are also consistent with this process. The advent of the euro - which removed currency risk - and the general increase in financial interconnectedness meant that as core area banks looked for opportunities, the periphery and Baltics were easy locations for money to flow.
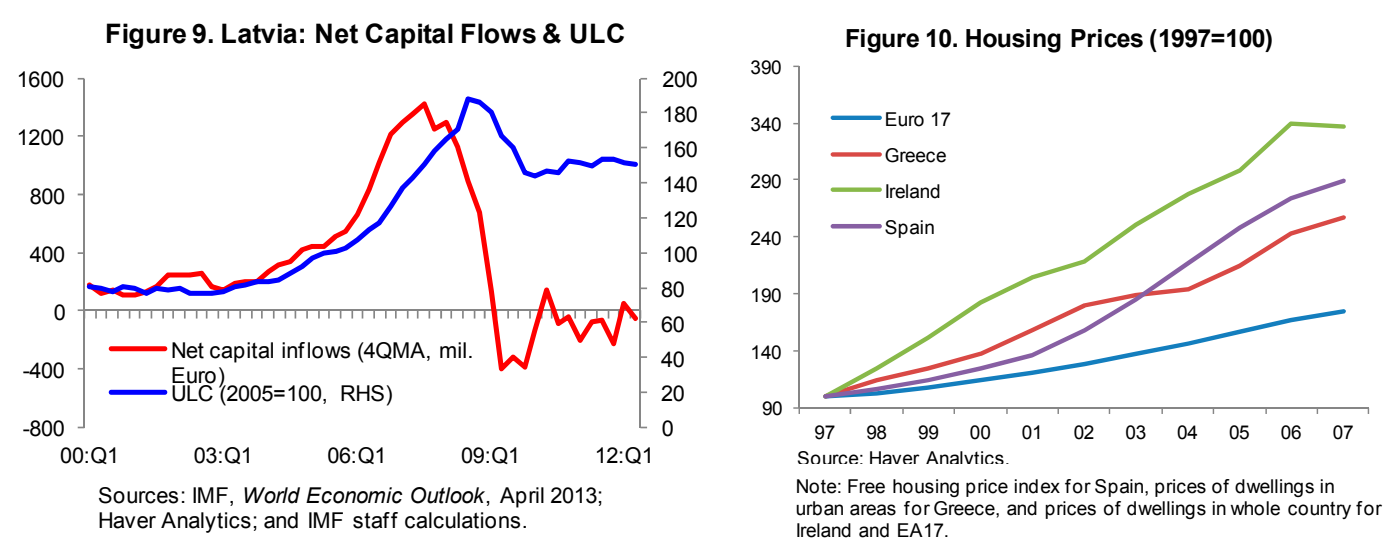

High expected growth can also lead to a domestic demand boom and rising imports. This boom typically leads to a strong pick up in consumption and investment, leading to strong economic growth and corresponding imports. ${ }^{12}$ In this case, the ULC in the non-tradable sector increases much faster than that in the tradable sector. A domestic demand boom can also lead to a housing boom, in which case we can also observe a strong increase in housing prices as well as strong growth in residential investment. Figure 11 shows the experience of Portugal in the 1990s. Portugal's trade balance deteriorated by about 4 percentage points of GDP from 1993 to 2000 on the back of domestic demand-driven economic growth. The contribution of consumption to GDP growth increased and, while exports continued to grow, imports grew faster, subtracting more and more from net growth. A similar pattern is observed in the Baltics in the 2000s (see next section).

In many ways, the difference between an optimism-led boom, which pulls in capital from abroad, and a capital flow-induced boom are difficult to establish. Both will lead to rising home prices, rising ULCs, and a temporary boom in output. The only difference is the impetus of the flow of funds from abroad-push or pull.

Large fiscal spending also contributes to a domestic demand boom. Higher wages and more employment for public servants would lead to higher output, but ULC would increase, in particular in the public sector, and the fiscal balance could deteriorate significantly. Greece

${ }^{12}$ See Lane and Pels (2012) for more discussion. 
fits this pattern (Figure 12), but outside of Greece, government balances were either flat or improving in most euro area periphery and Baltic countries in the run-up to the crisis.

Figure 11. Portugal: Growth Decomposition (In percentage points)

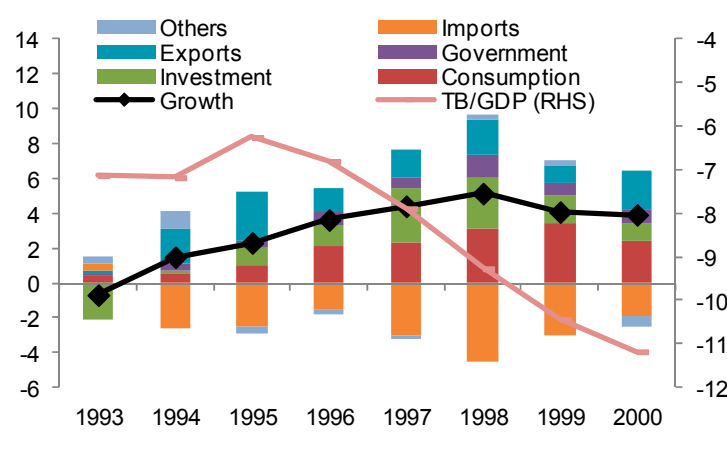

Source: IMF, World Economic Outlook, April 2013.
Figure 12. Greece: Fiscal Balance and ULC

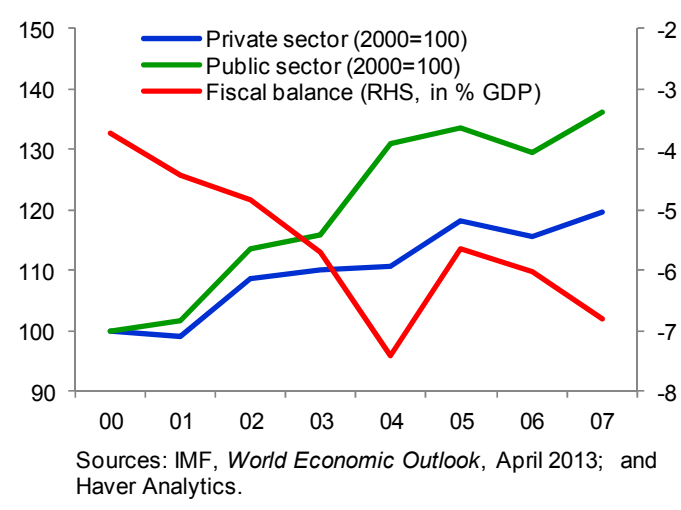

\section{Non-Trade Components}

Changes in non-trade components are also important factors. In theory, a transfer of wealth from abroad should lead to an increase in consumption and investment and a shift towards trade deficit. A decline in these transfers should lead to a reduction in consumption and a return to trade account balance as the country adjusts to its lower income. However, that does not happen if there is habit persistence and households and firms maintain the same level of spending by borrowing when transfers decline. Output and ULC would remain flat, but the current account would deteriorate as consumption and imports do not decline. In both Portugal and Greece, loans replacing declining transfers led to a persistent failure to adjust to trade deficits that were present and led to growing current account deficits through both declining transfers and subsequently rising net income payments (Figures 13 and 14). In both countries, trade deficits have been in excess of 5 percent of GDP since the early 1980s. At many times, though, current accounts have been close to balance. When the transfers declined, however, the trade balances did not. ${ }^{13}$

\footnotetext{
${ }^{13}$ The detailed country sections walk through the changes in transfers in more detail. Some of the decline in Portugal's case in the mid-1990s comes as EU funds are rebooked from the current to capital account. While, they still cause a worsening of the current account, they do only in a formal accounting sense. Funds are still flowing in to the country. However, this change is relatively small compared to the overall loss of transfers they faced.
} 

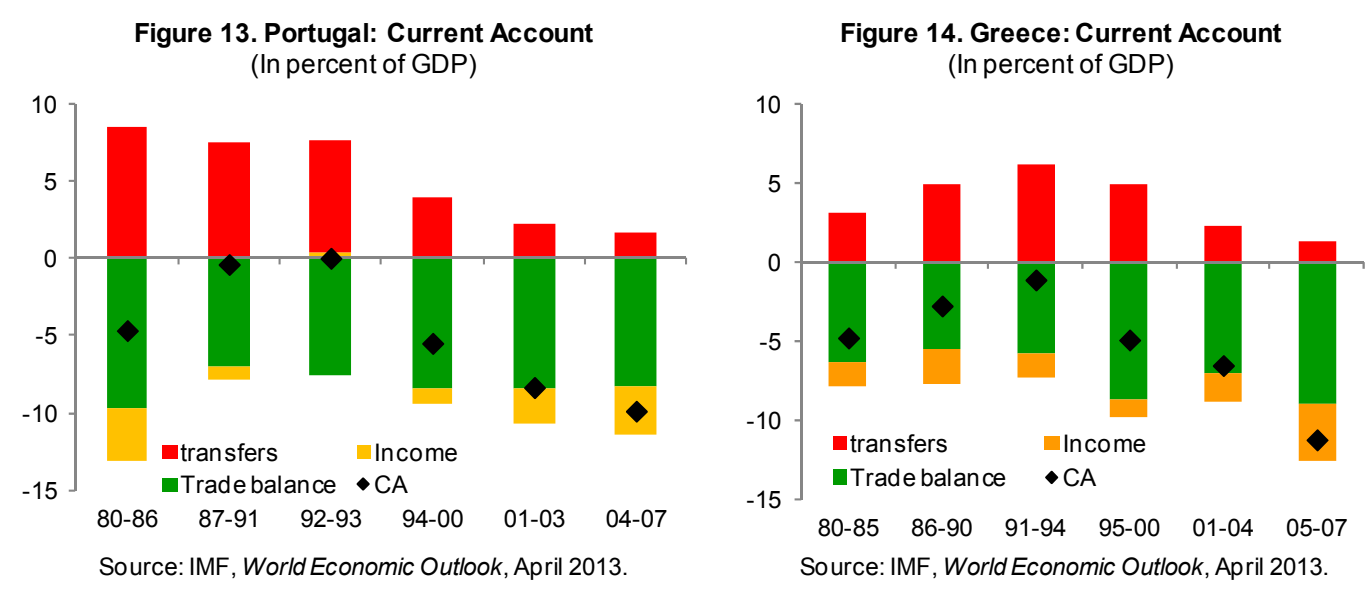

Additionally, by running persistent current account deficits, all of these countries saw rising net income deficits as they had to pay more to support their growing external debt as well as FDI-related income outflows. The large current account deficits are not simply a feature of the last few years. Nearly all of these countries had large deficits when the euro launched. As these deficits accumulated, the cost of financing external debt became a larger and larger feature of the current account. Figure 15 shows that the net income balance worsened by an average of 2 to 3 percent of GDP over this period. Thus, even if countries returned trade balances to their 1999 levels, the current account deficits would be much larger than before.

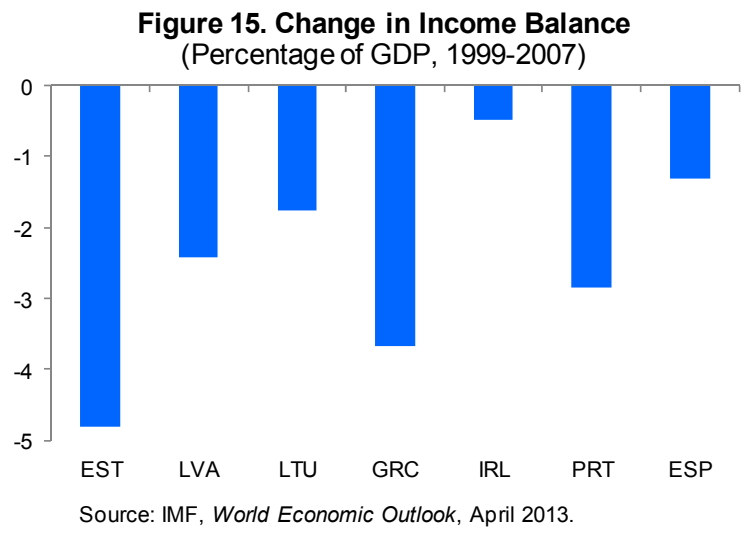

\section{Current AcCount Developments for Individual Countries}

There were differences across countries in terms of the timing and origins of the shocks that led to the build up of large current account deficits in the run up to the crisis. While all of these explanations lead to larger current account deficits and unsustainably high relative prices, as discussed above, they differ widely in their predictions for domestic growth, export performance, and other macroeconomic indicators. As we discuss more in detail below, the trend of current account deterioration began even before the inception of the Euro, and different and overlapping factors played different roles for each individual country.

\section{A. Greece}

Greece embodies nearly every element that contributes to worsening current account balances: a domestic boom, fiscal deficits, declining transfers, and growing net income payments. In particular, as transfers declined, spending did not and borrowing increased such 
that there was a persistent failure to adjust to imbalances that were already present. This helped generate growing current account deficits through rising net income payments. The problem lies not in a substantial collapse in competitiveness, but with a persistent failure to adjust to imbalances that were present at the start of the Euro. While export performance remained stable, the trade balance deteriorated somewhat as expectations for higher growth and large fiscal deficits for extended periods led to a surge in domestic demand and rising imports.

The trade balance in Greece has not been near balance for the last 30 years, but current account deficits were much lower than trade deficits as large transfers filled the gap (Figure 16). In 1994, despite a trade deficit of more than 5 percent of GDP, the current account deficit was only 0.1 percent of GDP. Since then, the current account gradually deteriorated to a deficit of about $14 \frac{1}{2}$ percent of GDP in 2007. Over this period, while the trade balance deteriorated by about 6 percentage point of GDP, the decline in transfers and increase in income payments accounted for current account deterioration of more than $81 / 2$ percentage points of GDP. Despite the decline in transfers, consumption and investment did not decrease as households and business were able to borrow. As a result, net income payments increased during this period. The decline in transfers was both a function of declining remittances from abroad as well as a decline in official transfers (Figure 17). Combined, transfers peaked at roughly 7 percent of GDP in the mid 1990s, but by 2007, they were less than 1 percent of GDP.

Figure 16. Greece: Current Account (In percent of GDP)

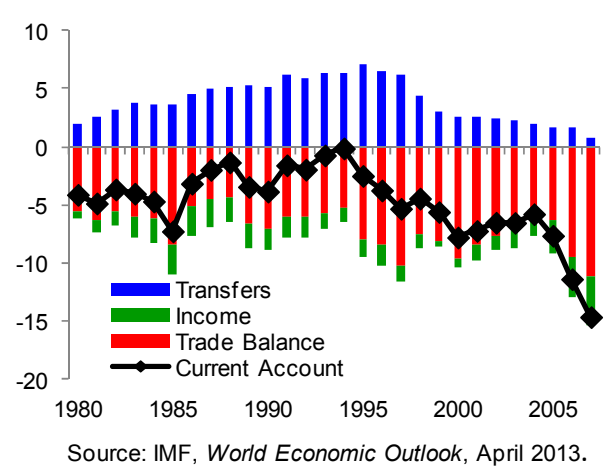

Figure 17. Greece: Transfers (In percent of GDP)

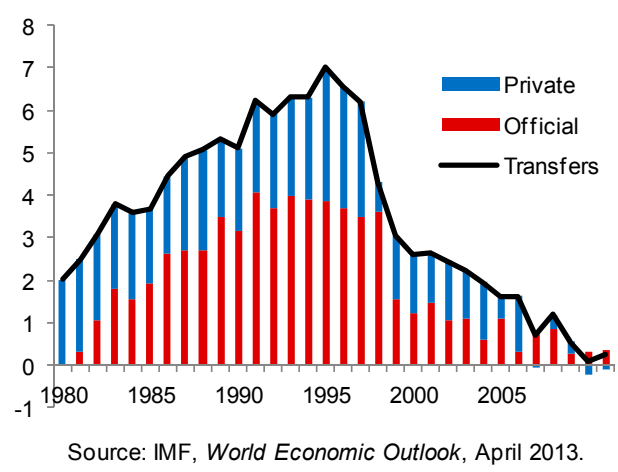

The trade balance also deteriorated over this period, but not necessarily due to a loss of competitiveness in export sectors. Merchandise exports, which deteriorated significantly from mid-1980s to mid-1990s on the back of sizable appreciation of manufacturing ULC based-REER, rebounded since 1997. REER appreciation was less than 10 percent for next 10 years and the merchandise export market share did not decline further, leading to a rebound in merchandise exports-to-GDP ratio by about 3 percentage point of GDP. ULC increase in the service sector was very limited over this period, leading to a strong performance of service exports, with service export-to-GDP ratio rising by about 6 percentage points of GDP. 
In contrast, expectation of higher growth has led to

Figure 18. Greece: Growth Contribution (In percentage points) a strong increase in consumption and investment and corresponding imports since mid-1990s (Figure 18). Housing prices also picked up and residential investment, which contributed little to economic growth for the previous 10 years, posted strong growth since the mid-1990s (Figure 19). Fiscal deficits remained high at more than 5 percent of GDP, contributing to a domestic demand boom. On net, exports grew as a share of GDP from an average of 14 percent in 1995-99 to 21.9 percent in 2007 while imports grew from 22.5 percent to 33.1 percent, so the trade balance declined 2.7 percentage points of GDP. The marked difference in ULC developments between tradable and non-tradable sectors is consistent with strong export performance and a domestic demand-driven import surge (Figure 20).
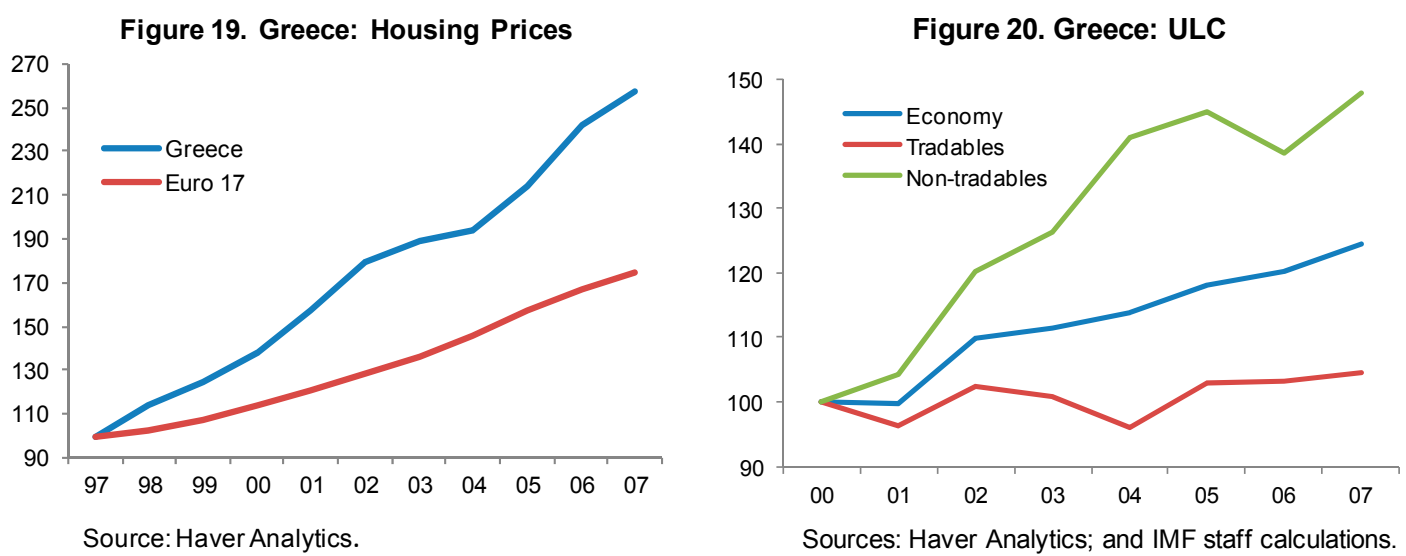

\section{B. Portugal}

Portugal experienced a steady deterioration of the current account as declining transfers did not generate declining expenditure but rather households and firms maintained expenditure and aggregate borrowing increased while the trade balance remained relatively stable.

Despite a large trade deficit of 7-8 percent of GDP, the current account was near balance in 1992-93, but steadily deteriorated since then to a deficit of more than 10 percent of GDP in 2007 (Figure 21). Trade has played little role in the growing imbalances since 2000 as there appears to have been little domestic boom or export decline. 
Figure 21. Portugal: Current

Account

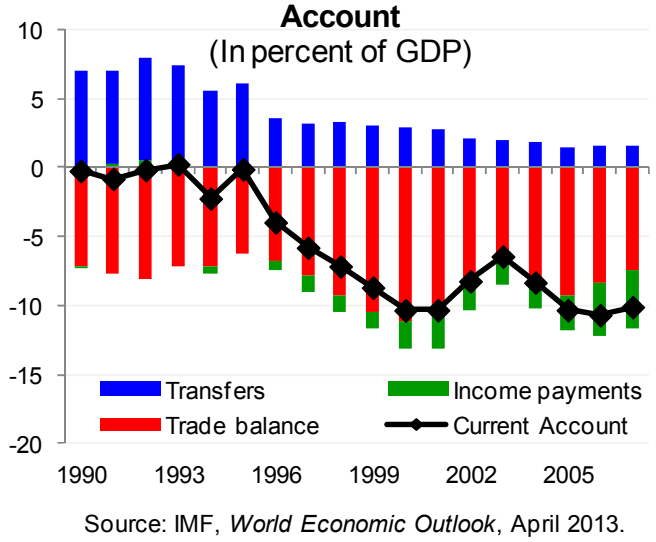

Figure 22. Portugal: Transfers (In percent of GDP)

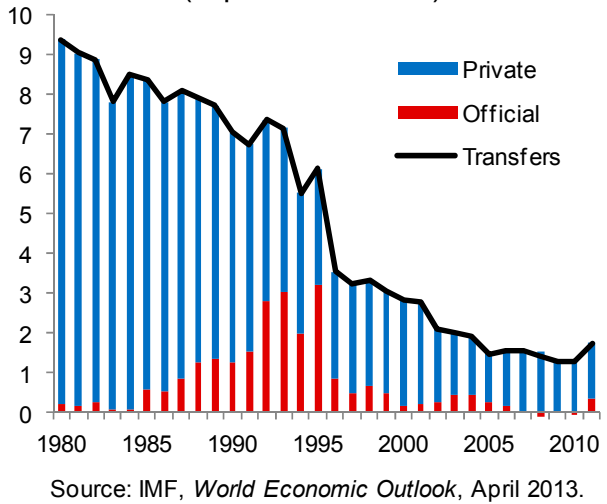

Non-trade factors have dominated the current account movements. Over this period, transfers declined by about 6 percentage points of GDP, and net income payments increased by $4 \frac{1}{2}$ percentage point of GDP, accounting for all the deterioration of the current account.

Remittances started to come down sharply around the mid-1990s due to two effects. First, while there was massive outward migration during the 1960s and 1970s, Portugal turned a net immigration country, attracting inward migrants in particular from Brazil and Eastern Europe. Second, rapidly rising disposable income levels and availability of cheap credit reduced the need for transfers from the Portuguese abroad. As noted in footnote 12, some portion of the decline in transfers was an accounting feature of moving official EU structural adjustment funds from the current to capital account. (This explains some of the drop in the red bar around 1995 in Figure 22). ${ }^{14}$ However, private transfers have declined substantially and official transfers have continued to decline from this rebooking.

The trade balance remained relatively stable with some deterioration in 1990s and reversals in 2000s, as growth in exports offset rising imports. In the mid-1990s, expectations of higher growth led to a strong increase in consumption and investment, leading to higher growth (Figure 23). With little appreciation of manufacturing ULCbased REER, exports grew strongly during this period, but import growth outpaced export growth, leading to a deterioration of the trade balance. While domestic demand growth somewhat slowed in the 2000s, especially investment, exports continued to grow, leading to an improvement in the trade balance.

Figure 23. Portugal: Growth Contribution (In percentage points)

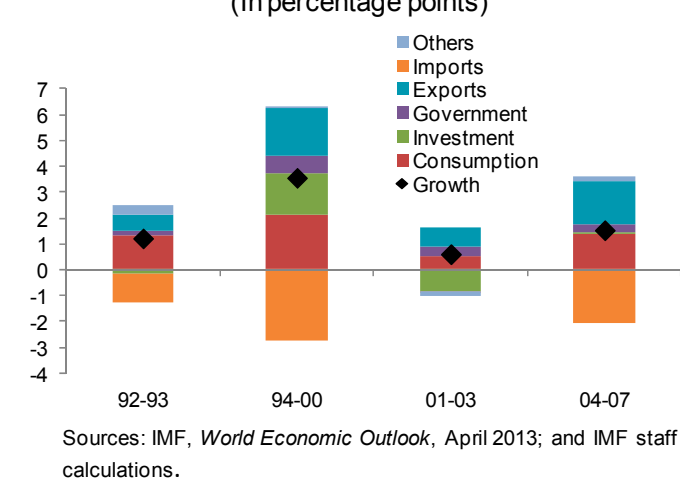

\footnotetext{
${ }^{14}$ It is not easy to exactly estimate the size of official EU structural adjustment funds that were rebooked from the current to the capital account since the official breakdown of transfers into capital and current transfers by the Portuguese central bank began in 1996.
} 


\section{Spain}

In Spain, the current account was near balance in 1997, but deteriorated since then to a deficit of 10 percent of GDP in 2007, largely due to deterioration of the trade balance (Figure 24), though a growing net income gap and some decline in transfers contributed (See Figure 7). Export performance remained relatively stable over this period. Despite some loss in merchandise export market share due to rising cost as mirrored in appreciation of the manufacturing ULC-based REER by about 20 percent, the exports-to-GDP ratio remained stable and exports continued their contribution to growth over this period.

A housing boom and associated capital inflow, along with strong domestic demand growth, led to large increase in import demand. Since the late-1990s, housing demand picked up, leading to a sharp increase in housing prices and strong growth of residential investment, which accounted for more than half of investment growth during this period (Figure 25). With the integration of financial markets in the Euro area, capital inflow surged and consumers and business were able to continue to borrow at much lower rates than before, leading to a strong pick up in consumption and investment (Figures 26 and 27). A persistent imbalance has also generated a rising net income gap.

Figure 24. Spain: Current Account (In percent of GDP)

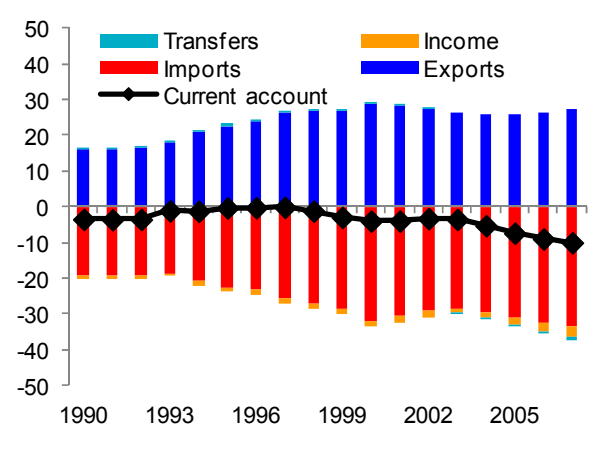

Source: IMF, World Economic Outlook, April 2013.

Figure 26. Spain: Net Capital Flows \& ULC

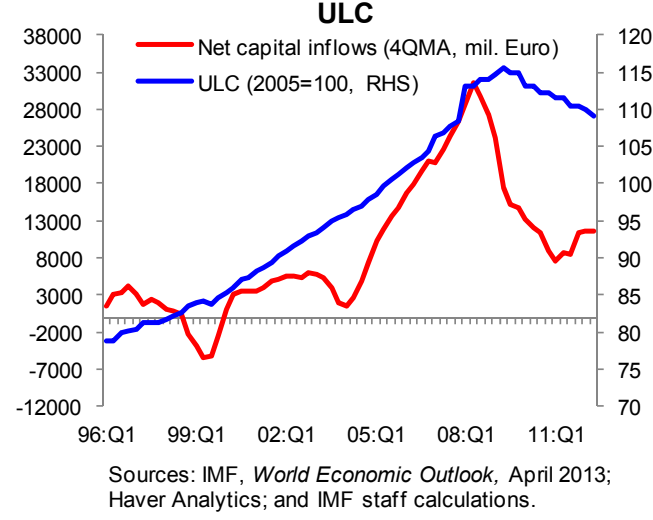

Figure 25. Spain: Housing Prices

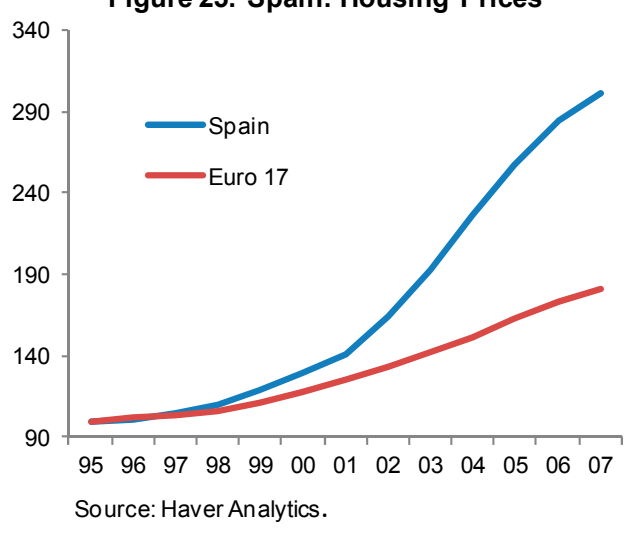

Figure 27. Spain: Growth Decomposition (In percentage points)

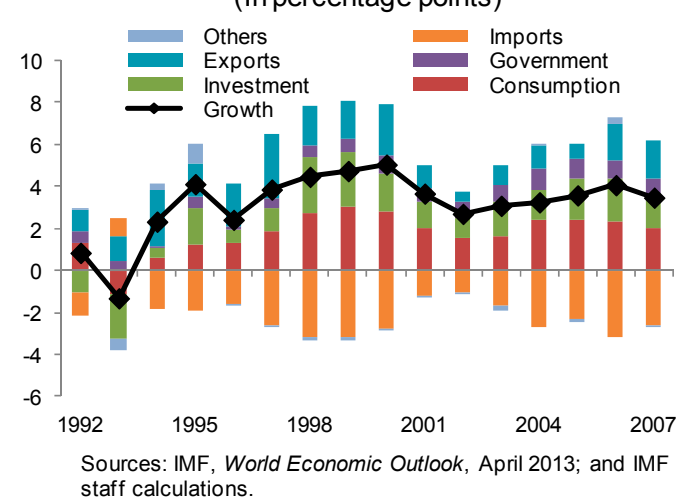




\section{Ireland}

Ireland experienced a capital inflow-driven domestic boom, especially in the housing market, which contributed to a gradual deterioration of current account over the last decade. The current account deficit was smaller than the other peripheral European countries and the Baltics in the run up to the crisis at about 51/2 percent of GDP in 2007, but Ireland also experienced a steady deterioration by about 9 percentage points in the previous 10 years.

While it has always had a trade surplus balanced by an income deficit, in the five years before the crisis, the trade surplus declined as imports grew faster than exports (Figure 28). The trade balance deteriorated by roughly 3 percentage points, and a continued increase in net income payments contributed roughly 3 percentage points, followed by decline in transfers by more than 3 percentage points.

In the 1990s, Ireland experienced strong growth on the back of large FDI inflows and productivity growth. Since the mid-1990s, the economy also made a structural transition to service-based economy, leading to a surge in service exports and imports while merchandise trade declined significantly together with goods market share despite a depreciation of the manufacturing ULC-based REER.

Figure 28. Ireland: Current Account (In percent of GDP)

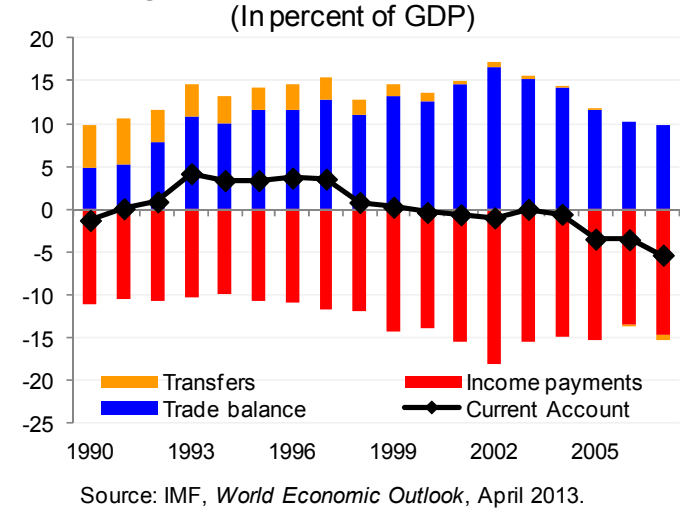

Figure 29. Ireland: Net Capital Flows \& ULC

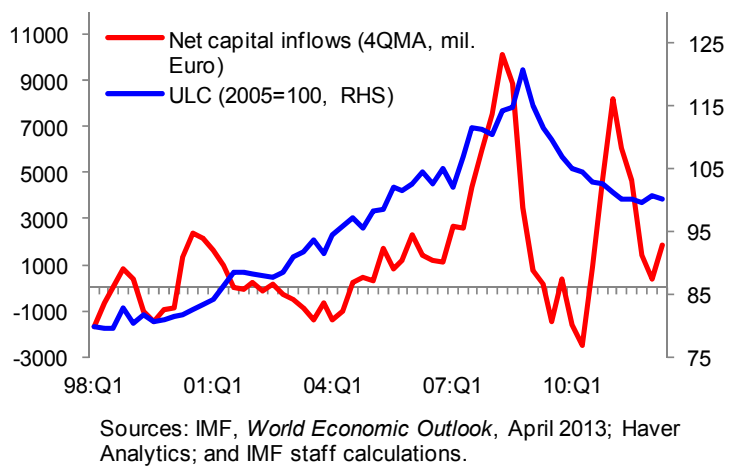

With the inception of the Euro, Ireland experienced a domestic demand boom, in particular in the non-tradable sector including a property boom (both commercial real estate and housing), on the back of capital inflows and low interest rates (Figure 29). Housing price increased sharply and the ULC in the non-tradable sector surged while the ULC in the tradable sector actually declined in the run up to the crisis (Figures 30 and 31). While the fiscal balance remained in surplus on the back of strong revenue gains, fiscal spending increased sharply on rising wages and employment, leading to a significant increase in cyclically adjusted fiscal deficits. ${ }^{15}$

${ }^{15}$ Nkusu (2012). 
Figure 30. Ireland: Housing Prices

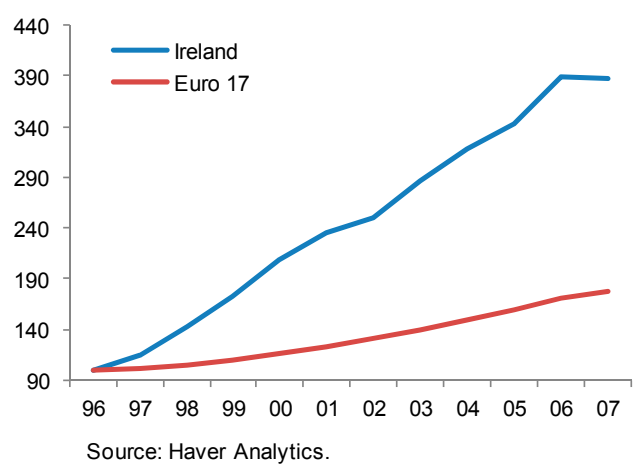

Figure 31. Ireland: ULC

(2000Q1=100)

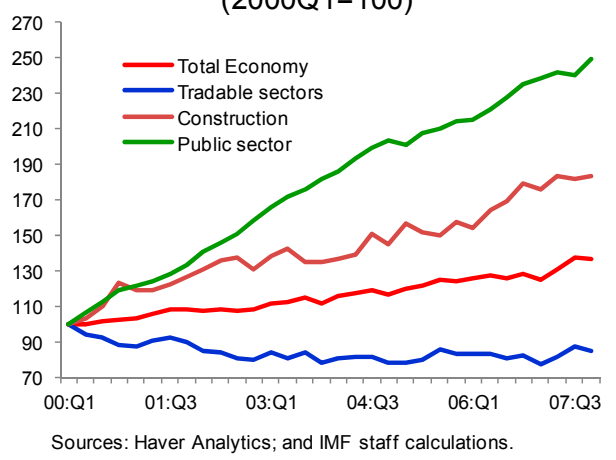

\section{E. The Baltics}

Both trade and current account deficits have been large since independence for all three Baltic countries and were growing heading into the crisis (Figures 32-34). In Estonia, declining transfers and growing income payments also helped trigger a sharply larger current account deficit (Figure 35). In the 2000s, export sector performance remained strong, with varying degrees, as can be seen in continued gain in global merchandise export market shares. In particular, Lithuania's ULC increase in the tradable sector was much more limited than the other two, corresponding with larger gains in export market share (Figure 36). However, Estonia's export growth somewhat slowed in mid-2000s on the back of rising costs in the tradable sector. In all three countries, imports grew faster than exports due to the strong domestic demand (Figure 37).
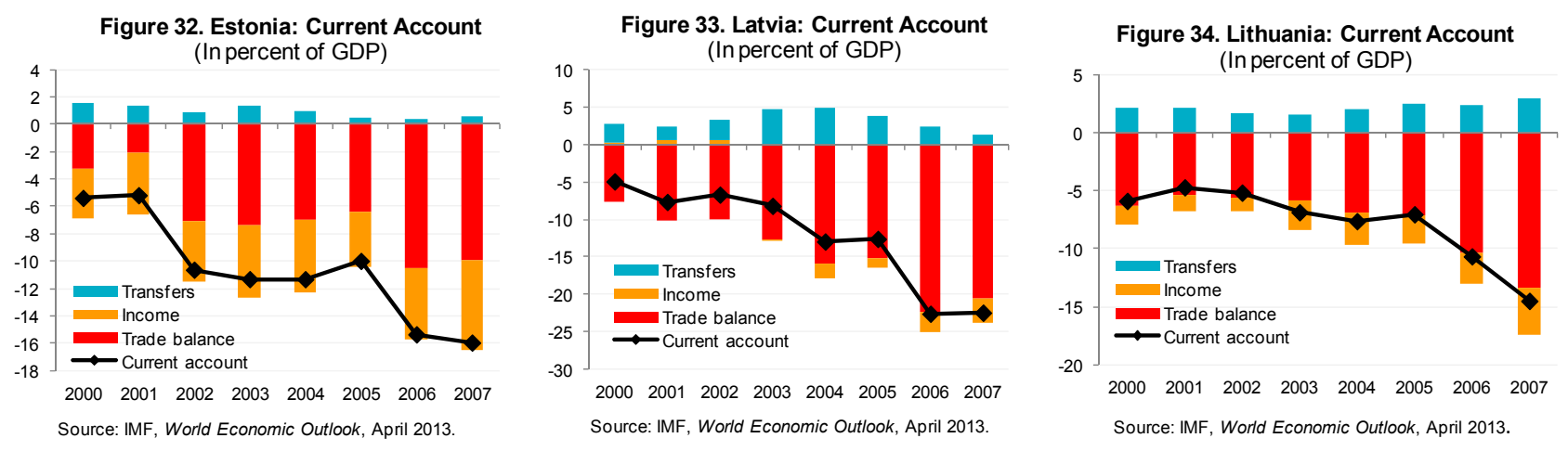

The Baltic countries experienced capital inflow-driven domestic booms in the 2000s, especially in non-tradable sectors (Figures 38-40). Domestic demand booms led to strong increases in ULC in all three countries, notably in non-tradable sectors. Total economy ULCbased REER appreciated much more than manufacturing ULC-based REER in Estonia (not 
available for the other two), consistent with a large boom in non-tradable sectors. ${ }^{16}$ Thus, the Baltics appear to be consistent with a classic boom-driven import increase.
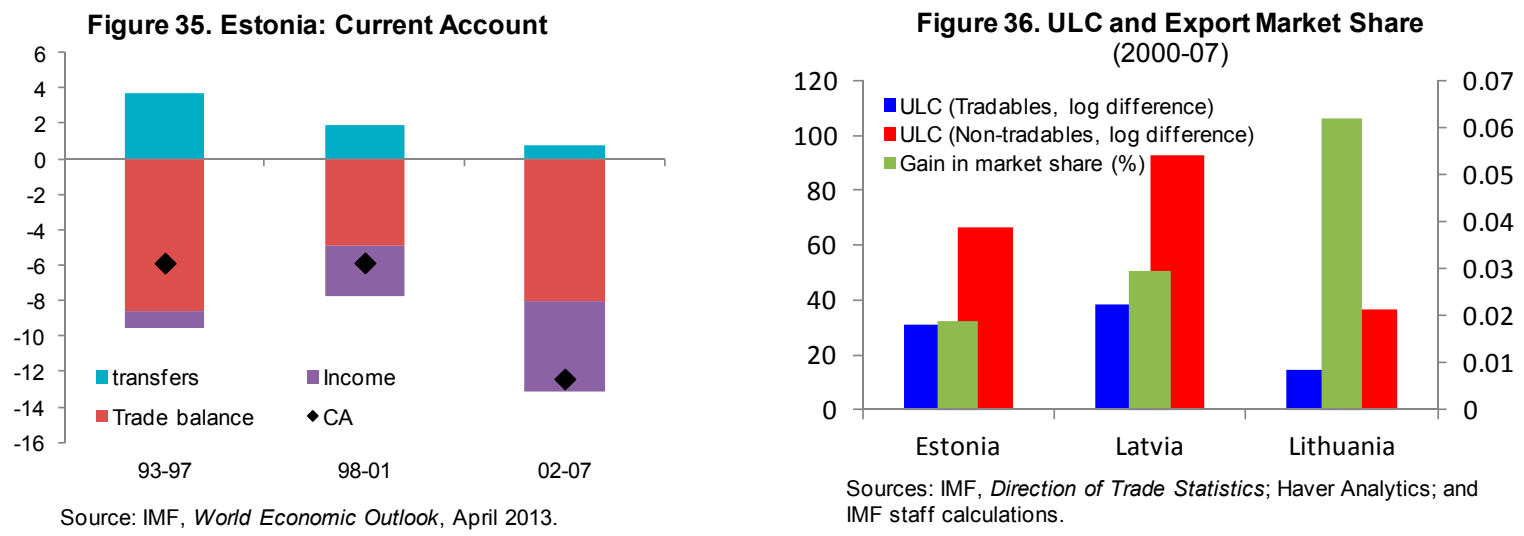

Sources: IMF, Direction of Trade Statistics; Haver Analytics; and IMF staff calculations.

Figure 37. Export \& Import Volume Growth (In percent, 2000-07)

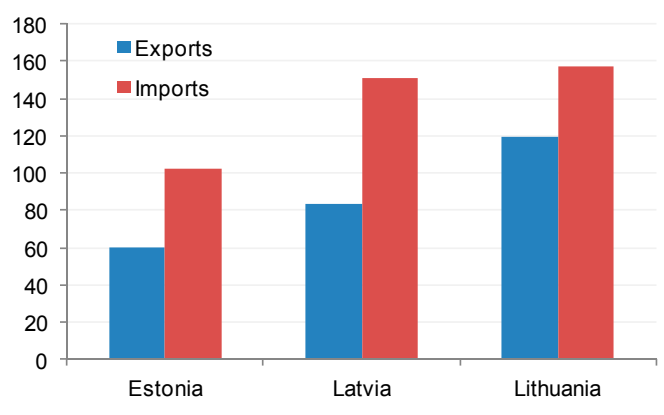

Figure 38. Estonia: Growth Decomposition

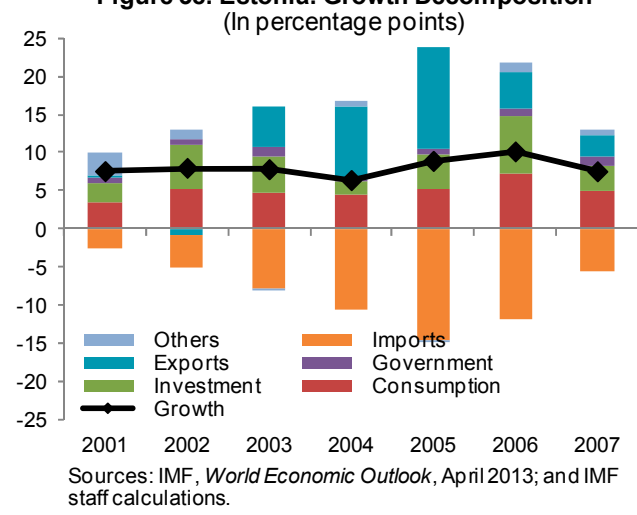

Figure 39. Latvia: Growth Decomposition (In percentage points)

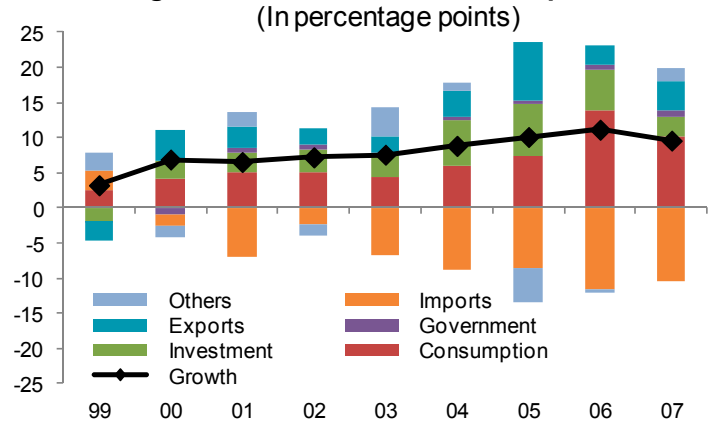

Figure 40. Lithuania: Growth

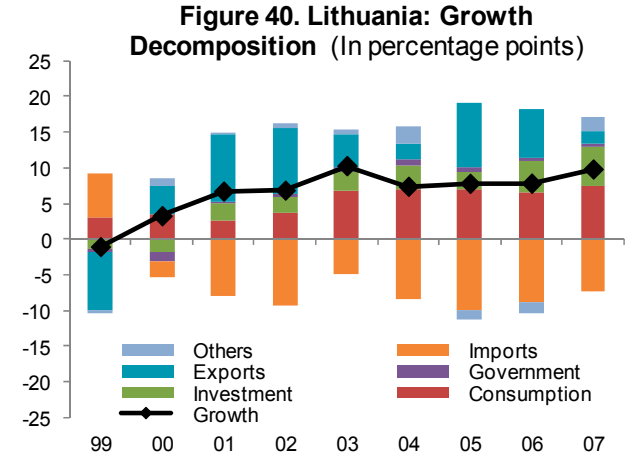

Sources: IMF, World Economic Outlook, April 2013; and IMF staff calculations. staff calculations.

\footnotetext{
${ }^{16}$ Fiscal policy in Estonia during the boom period was pro-cyclical, with the structural fiscal balance in deep deficit, contributing to domestic demand boom and widening current account deficits.
} 


\section{Conclusion}

Leading into the crisis, both the euro area periphery and the Baltics faced large and growing current account deficits. The root causes of these deficits appear quite different across countries. A common feature, however, is that despite rising unit labor costs on whole economy measures, these countries by and large did not suffer declines in export performance. Instead, the growing current account deficits seem driven by import increases and non-trade factors. Some - most notably the Baltics, but to some extent Spain, Greece, and Ireland - appear to have experienced large capital inflows and optimism-driven booms. This raised unit labor costs in the non-tradable sector and increased imports. Others-notably Greece and Portugal - saw declines in the transfers they received from abroad which worsened the current account. Strong fiscal profligacy in Greece also contributed widening current account deficits. All saw declining net income balances as their persistent current account deficits required higher payments abroad. Given that fiscal problems were generally not an issue as much as overall borrowing by the economy (due to demand booms, lending booms or borrowing to maintain spending when transfers declined), it seems that surveillance on fiscal policy alone is apt to miss economic vulnerabilities.

Since the crisis, price measures have reversed, though not yet to pre-1999 levels, and current account deficits have shrunk. Part of this improvement is cyclical and part may be structural, but it is difficult to distinguish. A large part of the current account improvement still rests on import contraction, and much of the productivity improvement stems from labor shedding (Figures 41-46). ${ }^{17}$ Furthermore, with unemployment at very high levels, this suggests sizable output gaps which would imply still large cyclically-adjusted current account deficits in most countries. ${ }^{18}$ Conversely, the unwinding of the unsustainable consumption booms suggests that some portion of the import contraction is sustainable and the improvements in unit labor costs are helping to generate increased exports recently in some countries.

Still, a substantial relative price adjustment is likely necessary for more sizable gains in export performance so deficits do not re-emerge as these countries recover towards full employment. Even though deterioration of competitiveness in their export sector was not a major factor behind large current account deficits, they still need relative price adjustment. Regardless of the underlying causes of external imbalances, with the sizable accumulation of net foreign claims over the last decade and declining net income balances, they need depreciation to improve external balances. Also, with weak domestic demand and sizable output gaps, an improvement in external demand would be helpful. At the same time, external financing support will be needed, in part to offset the high net income payments, while they adjust. Finally, while relative price adjustment may help to boost competitiveness,

\footnotetext{
${ }^{17}$ See Kang and Shambaugh (2013) for discussion on the progress towards internal devaluation after the crisis.

${ }^{18}$ Ireland and Estonia have made more progress towards cyclically-adjusted current account balance and likely do not need more real depreciation.
} 
it is important to also sustain nominal GDP growth to avoid exacerbating debt sustainability in the euro area periphery where both sovereign debt and private debt burdens are high. ${ }^{19}$

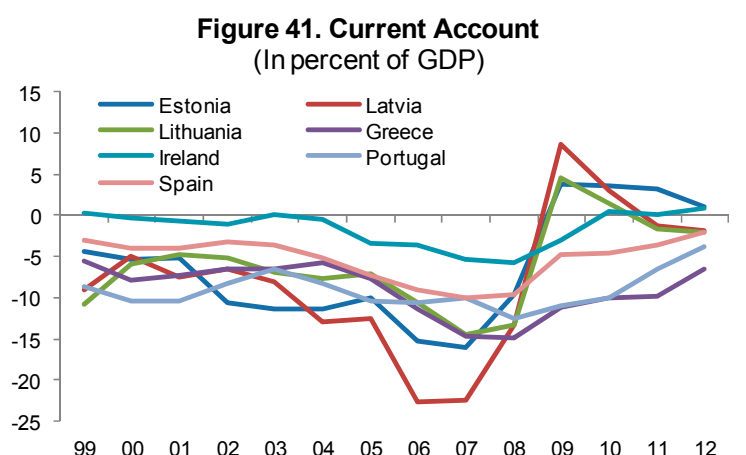

Source: IMF, World Economic Outlook, April 2013.

Figure 43. GDP Deflator-Based REER

(ULC peak - 2012Q3, log difference)

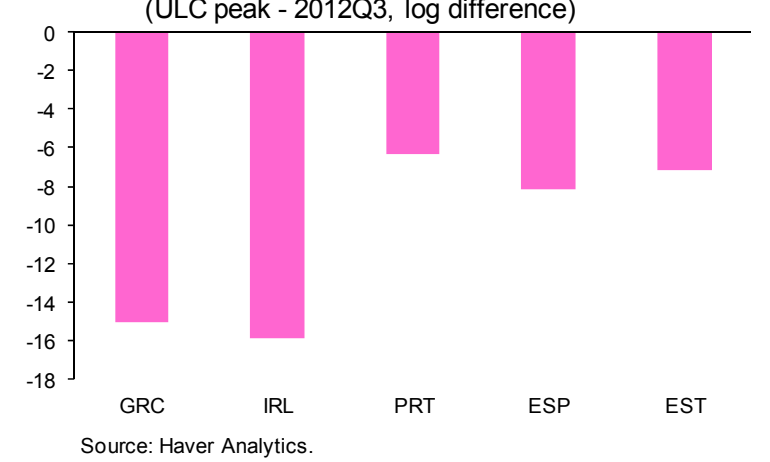

Source: Haver Analytics.

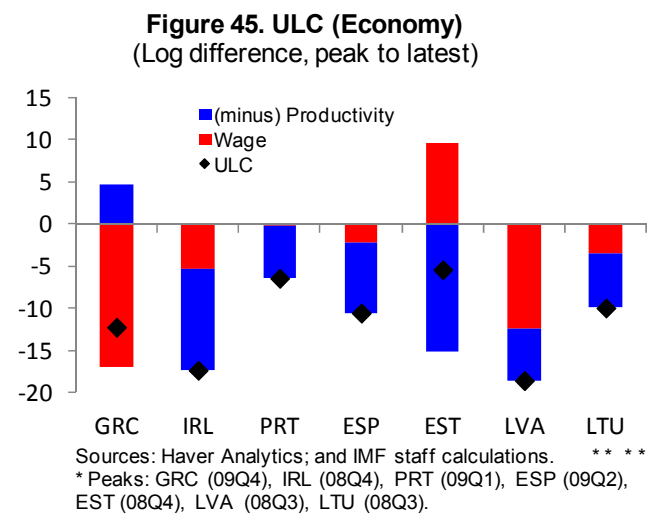

${ }^{19}$ See Shambaugh (2012) for more detailed discussion.

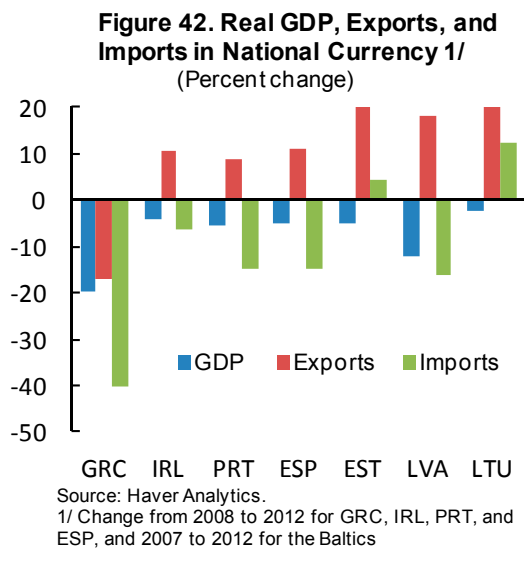

Figure 44. ULC (Economy)-Based REER (ULC peak - 2012Q2, log difference)

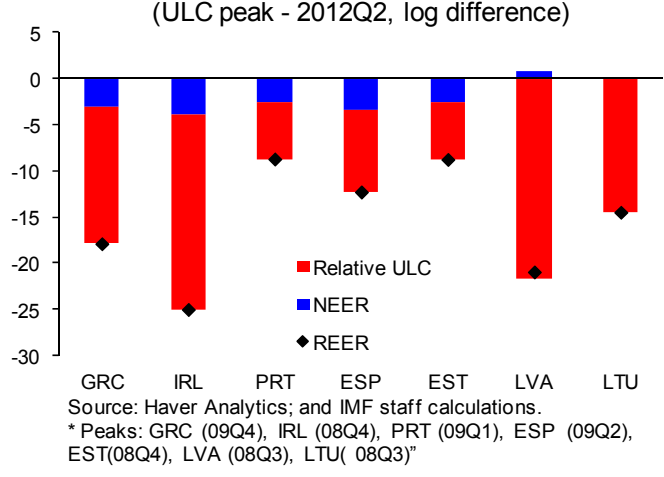

Figure 46. Productivity (Economy)

(Log difference, peak to latest)

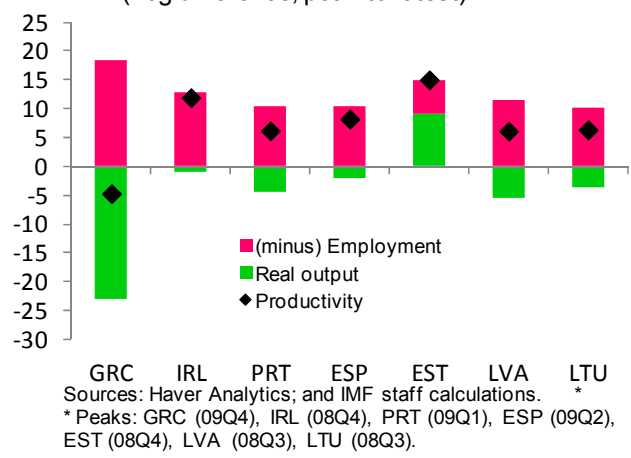




\section{References}

Atoyan, Ruben, Jonathan Manning, and Jesmin Rahman, 2013, "Rebalancing: Evidence from Current Account Adjustment in Europe," IMF Working Paper, WP/13/74 (Washington: International Monetary Fund).

Bakker, Bas, and Christoph Klingen, 2012, "How Emerging Europe Came Through the 2008/09 Crisis: An Account by the Staff of the IMF's European Department" (Washington: International Monetary Fund).

Bayoumi, Tamim, Richard Harmsen, and Jarkko Turunen, 2011, "Euro Area Export Performance and Competitiveness," IMF Working Paper, WP/11/140 (Washington: International Monetary Fund).

Bems, Rudolph, and Robert Johnson, 2012, "Value-Added Exchange Rates," NBER WP 18498 (Cambridge, Massachusetts: National Bureau of Economic Research).

Berger, Helge and Volker Nitsch, 2010, “The Euro's Effect on Trade Imbalances," IMF Working Paper, WP/10/226 (Washington: International Monetary Fund).

Chen, Ruo, Gian-Maria Milesi-Ferretti, and Thiery Tressel, 2012, "External Imbalances in the Euro Area," IMF WP No. 12/236 (Washington: International Monetary Fund).

Gaulier, Guillaume, and Vincent Vicard, 2012, "Current Account Imbalances in the Euro Area: Competitiveness or Demand Shock," Bank of France Quarterly Selection of Articles No. 27.

Holinski, Nils, Clemens Kool, and Joan Muysken, 2012, "Persistent Macroeconomic Imbalances in the Euro Area: Causes and Consequences," Federal Reserve Bank of St. Louis Review, January/February 2012.

Ivanova, Anna, 2012, "Current Account Imbalances: Can Structural Policies Make a Difference?” IMF Working Paper, WP/12/61 (Washington: International Monetary Fund).

Jaumotte, Florence, and Piyaporn Sodsriwiboon, 2010, "Current Account Imbalances in the Southern Euro Area," IMF Working Paper, WP/10/139 (Washington: International Monetary Fund).

Kang, Joong Shik, and Jay C. Shambaugh, 2013, "Progress Toward Internal Devaluation in the Euro Area Periphery and the Baltics," manuscript (Washington: International Monetary Fund).

Lane, Philip, and Barbara Pels, 2012, "Current Account Imbalances in Europe," CEPR Discussion Paper No. DP8958.

Nkusu, Mwanza, 2013, "Boosting Competitiveness to Grow Out of Debt — Can Ireland Find a Way Back to Its Future?” IMF WP 13/35 (Washington: International Monetary Fund).

Shambaugh, Jay, 2012, “The Euro's Three Crises," Brookings Papers on Economic Activity, Spring 2012, pp 157-211. 
Appendix. Merchandise Export Market Share

\author{
Merchandise Export Market Shares (in percent)
}

\begin{tabular}{|c|c|c|c|c|c|c|c|c|c|c|c|c|c|}
\hline & 1995 & 1996 & 1997 & 1998 & 1999 & 2000 & 2001 & 2002 & 2003 & 2004 & 2005 & 2006 & 2007 \\
\hline \multicolumn{14}{|l|}{ Greece } \\
\hline World & 0.213 & 0.222 & 0.199 & 0.194 & 0.180 & 0.167 & 0.153 & 0.156 & 0.173 & 0.162 & 0.161 & 0.168 & 0.165 \\
\hline Advanced Economies & 0.203 & 0.197 & 0.173 & 0.172 & 0.157 & 0.131 & 0.123 & 0.115 & 0.150 & 0.140 & 0.137 & 0.144 & 0.143 \\
\hline Euro Area & 0.430 & 0.414 & 0.340 & 0.319 & 0.290 & 0.241 & 0.208 & 0.197 & 0.255 & 0.236 & 0.236 & 0.259 & 0.253 \\
\hline Other Advanced & 0.080 & 0.084 & 0.075 & 0.079 & 0.074 & 0.067 & 0.071 & 0.064 & 0.080 & 0.075 & 0.071 & 0.068 & 0.065 \\
\hline Emerging and Developing Economies & 0.248 & 0.307 & 0.279 & 0.265 & 0.263 & 0.292 & 0.251 & 0.250 & 0.238 & 0.218 & 0.218 & 0.224 & 0.200 \\
\hline Developing Asia & 0.035 & 0.050 & 0.034 & 0.019 & 0.030 & 0.030 & 0.025 & 0.042 & 0.023 & 0.018 & 0.020 & 0.023 & 0.021 \\
\hline Europe & 0.880 & 1.125 & 1.034 & 0.929 & 1.071 & 1.185 & 1.054 & 0.928 & 0.893 & 0.808 & 0.724 & 0.749 & 0.665 \\
\hline Middle East and North Africa & 0.423 & 0.458 & 0.374 & 0.366 & 0.315 & 0.396 & 0.312 & 0.344 & 0.302 & 0.292 & 0.323 & 0.347 & 0.213 \\
\hline Sub-Saharan Africa & 0.160 & 0.227 & 0.224 & 0.159 & 0.165 & 0.227 & 0.154 & 0.135 & 0.126 & 0.100 & 0.183 & 0.081 & 0.112 \\
\hline Western Hemisphere & 0.070 & 0.068 & 0.050 & 0.061 & 0.050 & 0.055 & 0.040 & 0.041 & 0.025 & 0.024 & 0.051 & 0.034 & 0.035 \\
\hline \multicolumn{14}{|l|}{ Ireland } \\
\hline World & 0.847 & 0.879 & 0.939 & 1.167 & 1.230 & 1.158 & 1.302 & 1.327 & 1.201 & 1.104 & 1.016 & 0.878 & 0.849 \\
\hline Advanced Economies & 0.979 & 1.000 & 1.083 & 1.379 & 1.415 & 1.327 & 1.509 & 1.587 & 1.481 & 1.395 & 1.302 & 1.121 & 1.105 \\
\hline Euro Area & 1.216 & 1.206 & 1.305 & 1.674 & 1.642 & 1.543 & 1.606 & 1.758 & 1.637 & 1.557 & 1.529 & 1.295 & 1.211 \\
\hline Other Advanced & 0.851 & 0.893 & 0.953 & 1.190 & 1.272 & 1.203 & 1.449 & 1.482 & 1.376 & 1.285 & 1.152 & 1.005 & 1.029 \\
\hline Emerging and Developing Economies & 0.301 & 0.333 & 0.379 & 0.380 & 0.462 & 0.381 & 0.428 & 0.388 & 0.304 & 0.259 & 0.251 & 0.262 & 0.261 \\
\hline Developing Asia & 0.151 & 0.237 & 0.228 & 0.261 & 0.408 & 0.339 & 0.432 & 0.302 & 0.243 & 0.207 & 0.223 & 0.231 & 0.247 \\
\hline Europe & 0.527 & 0.531 & 0.730 & 0.588 & 0.738 & 0.509 & 0.445 & 0.396 & 0.343 & 0.295 & 0.264 & 0.278 & 0.273 \\
\hline Middle East and North Africa & 0.586 & 0.510 & 0.536 & 0.599 & 0.666 & 0.640 & 0.578 & 0.874 & 0.398 & 0.318 & 0.280 & 0.286 & 0.289 \\
\hline Sub-Saharan Africa & 0.803 & 0.961 & 1.297 & 0.771 & 0.852 & 0.779 & 0.828 & 0.728 & 0.611 & 0.512 & 0.424 & 0.411 & 0.422 \\
\hline Western Hemisphere & 0.174 & 0.178 & 0.166 & 0.185 & 0.183 & 0.177 & 0.269 & 0.209 & 0.253 & 0.223 & 0.232 & 0.253 & 0.203 \\
\hline \multicolumn{14}{|l|}{ Portugal } \\
\hline World & 0.450 & 0.442 & 0.425 & 0.438 & 0.422 & 0.353 & 0.375 & 0.386 & 0.411 & 0.378 & 0.359 & 0.361 & 0.367 \\
\hline Advanced Economies & 0.527 & 0.517 & 0.499 & 0.515 & 0.497 & 0.413 & 0.442 & 0.457 & 0.490 & 0.456 & 0.438 & 0.441 & 0.449 \\
\hline Euro Area & 1.023 & 1.020 & 0.958 & 0.953 & 0.948 & 0.820 & 0.862 & 0.887 & 0.907 & 0.848 & 0.855 & 0.858 & 0.851 \\
\hline Other Advanced & 0.258 & 0.254 & 0.230 & 0.233 & 0.213 & 0.178 & 0.185 & 0.192 & 0.210 & 0.188 & 0.163 & 0.165 & 0.162 \\
\hline Emerging and Developing Economies & 0.160 & 0.170 & 0.132 & 0.159 & 0.135 & 0.133 & 0.143 & 0.147 & 0.155 & 0.145 & 0.137 & 0.148 & 0.166 \\
\hline Developing Asia & 0.038 & 0.033 & 0.028 & 0.030 & 0.032 & 0.026 & 0.025 & 0.031 & 0.036 & 0.041 & 0.034 & 0.034 & 0.052 \\
\hline Europe & 0.111 & 0.152 & 0.106 & 0.131 & 0.129 & 0.143 & 0.140 & 0.159 & 0.168 & 0.145 & 0.157 & 0.157 & 0.147 \\
\hline Middle East and North Africa & 0.226 & 0.207 & 0.160 & 0.161 & 0.152 & 0.171 & 0.195 & 0.182 & 0.207 & 0.182 & 0.166 & 0.148 & 0.149 \\
\hline Sub-Saharan Africa & 1.538 & 1.798 & 1.352 & 1.029 & 0.930 & 1.002 & 1.034 & 1.171 & 1.137 & 1.020 & 0.945 & 1.057 & 1.230 \\
\hline Western Hemisphere & 0.150 & 0.135 & 0.125 & 0.127 & 0.093 & 0.094 & 0.111 & 0.093 & 0.090 & 0.093 & 0.091 & 0.114 & 0.119 \\
\hline \multicolumn{14}{|l|}{ Spain } \\
\hline World & 1.781 & 1.894 & 1.860 & 1.944 & 1.781 & 1.641 & 1.711 & 1.787 & 2.011 & 1.922 & 1.782 & 1.716 & 1.761 \\
\hline Advanced Economies & 1.911 & 2.011 & 1.959 & 2.041 & 1.862 & 1.701 & 1.788 & 1.893 & 2.162 & 2.087 & 1.936 & 1.868 & 1.949 \\
\hline Euro Area & 3.896 & 4.161 & 3.941 & 3.923 & 3.610 & 3.440 & 3.473 & 3.641 & 4.050 & 3.873 & 3.618 & 3.467 & 3.498 \\
\hline Other Advanced & 0.836 & 0.887 & 0.798 & 0.832 & 0.766 & 0.700 & 0.756 & 0.815 & 0.893 & 0.868 & 0.826 & 0.809 & 0.841 \\
\hline Emerging and Developing Economies & 1.277 & 1.414 & 1.435 & 1.479 & 1.336 & 1.260 & 1.294 & 1.312 & 1.393 & 1.308 & 1.214 & 1.172 & 1.162 \\
\hline Developing Asia & 0.442 & 0.438 & 0.400 & 0.332 & 0.299 & 0.261 & 0.293 & 0.297 & 0.324 & 0.302 & 0.320 & 0.284 & 0.318 \\
\hline Europe & 1.338 & 1.606 & 1.776 & 1.809 & 1.914 & 2.094 & 1.939 & 2.017 & 2.106 & 2.113 & 1.915 & 1.783 & 1.766 \\
\hline Middle East and North Africa & 2.759 & 2.508 & 2.608 & 2.730 & 2.533 & 2.562 & 2.641 & 2.788 & 3.029 & 2.654 & 2.186 & 2.084 & 2.234 \\
\hline Sub-Saharan Africa & 1.963 & 2.528 & 2.812 & 1.726 & 1.771 & 1.389 & 1.578 & 1.575 & 1.684 & 1.405 & 1.402 & 1.311 & 1.210 \\
\hline Western Hemisphere & 1.866 & 2.186 & 2.004 & 1.896 & 1.608 & 1.512 & 1.610 & 1.659 & 1.866 & 1.746 & 1.731 & 1.811 & 1.534 \\
\hline
\end{tabular}


Merchandise Export Market Shares (in percent) (Con'd)

\begin{tabular}{|c|c|c|c|c|c|c|c|c|c|c|c|c|c|}
\hline & 1995 & 1996 & 1997 & 1998 & 1999 & 2000 & 2001 & 2002 & 2003 & 2004 & 2005 & 2006 & 2007 \\
\hline \multicolumn{14}{|l|}{ Estonia } \\
\hline World & 0.036 & 0.039 & 0.052 & 0.059 & 0.052 & 0.058 & 0.063 & 0.066 & 0.073 & 0.062 & 0.071 & 0.078 & 0.077 \\
\hline Advanced Economies & 0.028 & 0.029 & 0.038 & 0.047 & 0.046 & 0.057 & 0.056 & 0.057 & 0.065 & 0.061 & 0.068 & 0.065 & 0.067 \\
\hline Euro Area & 0.047 & 0.046 & 0.052 & 0.060 & 0.061 & 0.092 & 0.091 & 0.085 & 0.095 & 0.084 & 0.100 & 0.084 & 0.083 \\
\hline Other Advanced & 0.017 & 0.020 & 0.030 & 0.039 & 0.037 & 0.037 & 0.035 & 0.040 & 0.044 & 0.046 & 0.047 & 0.053 & 0.056 \\
\hline Emerging and Developing Economies & 0.065 & 0.072 & 0.100 & 0.099 & 0.072 & 0.063 & 0.077 & 0.085 & 0.097 & 0.064 & 0.079 & 0.109 & 0.098 \\
\hline Developing Asia & 0.001 & 0.001 & 0.002 & 0.003 & 0.004 & 0.005 & 0.007 & 0.008 & 0.008 & 0.001 & 0.006 & 0.021 & 0.008 \\
\hline Europe & 0.358 & 0.388 & 0.501 & 0.481 & 0.377 & 0.324 & 0.393 & 0.407 & 0.437 & 0.308 & 0.363 & 0.429 & 0.357 \\
\hline Middle East and North Africa & 0.001 & 0.003 & 0.008 & 0.010 & 0.013 & 0.014 & 0.015 & 0.016 & 0.013 & 0.006 & 0.007 & 0.021 & 0.023 \\
\hline Sub-Saharan Africa & 0.016 & 0.009 & 0.013 & 0.007 & 0.006 & 0.014 & 0.019 & 0.017 & 0.020 & 0.004 & 0.018 & 0.080 & 0.150 \\
\hline Western Hemisphere & 0.001 & 0.003 & 0.003 & 0.004 & 0.008 & 0.006 & 0.011 & 0.011 & 0.011 & 0.004 & 0.006 & 0.012 & 0.007 \\
\hline \multicolumn{14}{|l|}{ La tvia } \\
\hline World & 0.025 & 0.026 & 0.030 & 0.033 & 0.030 & 0.028 & 0.032 & 0.035 & 0.037 & 0.042 & 0.048 & 0.050 & 0.058 \\
\hline Advanced Economies & 0.017 & 0.017 & 0.023 & 0.029 & 0.029 & 0.028 & 0.031 & 0.034 & 0.038 & 0.040 & 0.045 & 0.044 & 0.050 \\
\hline Euro Area & 0.024 & 0.025 & 0.029 & 0.036 & 0.034 & 0.037 & 0.039 & 0.043 & 0.045 & 0.046 & 0.059 & 0.063 & 0.071 \\
\hline Other Advanced & 0.013 & 0.013 & 0.019 & 0.025 & 0.026 & 0.024 & 0.025 & 0.029 & 0.033 & 0.036 & 0.036 & 0.031 & 0.036 \\
\hline Emerging and Developing Economies & 0.055 & 0.057 & 0.053 & 0.045 & 0.032 & 0.027 & 0.037 & 0.036 & 0.035 & 0.043 & 0.054 & 0.064 & 0.075 \\
\hline Developing Asia & 0.001 & 0.002 & 0.003 & 0.002 & 0.001 & 0.001 & 0.001 & 0.001 & 0.003 & 0.002 & 0.002 & 0.003 & 0.003 \\
\hline Europe & 0.303 & 0.298 & 0.259 & 0.210 & 0.171 & 0.133 & 0.162 & 0.158 & 0.152 & 0.197 & 0.253 & 0.280 & 0.309 \\
\hline Middle East and North Africa & 0.005 & 0.018 & 0.011 & 0.012 & 0.010 & 0.019 & 0.050 & 0.042 & 0.015 & 0.009 & 0.007 & 0.017 & 0.019 \\
\hline Sub-Saharan Africa & 0.002 & 0.003 & 0.002 & 0.002 & 0.005 & 0.026 & 0.009 & 0.002 & 0.006 & 0.004 & 0.009 & 0.006 & 0.006 \\
\hline Western Hemisphere & 0.000 & 0.000 & 0.002 & 0.005 & 0.002 & 0.001 & 0.005 & 0.004 & 0.005 & 0.006 & 0.007 & 0.003 & 0.005 \\
\hline \multicolumn{14}{|l|}{ Lithuania } \\
\hline World & 0.053 & 0.061 & 0.069 & 0.067 & 0.052 & 0.058 & 0.072 & 0.083 & 0.093 & 0.098 & 0.109 & 0.114 & 0.120 \\
\hline Advanced Economies & 0.030 & 0.031 & 0.036 & 0.041 & 0.040 & 0.044 & 0.055 & 0.069 & 0.081 & 0.086 & 0.095 & 0.093 & 0.090 \\
\hline Euro Area & 0.056 & 0.062 & 0.065 & 0.068 & 0.064 & 0.068 & 0.072 & 0.088 & 0.098 & 0.117 & 0.131 & 0.127 & 0.130 \\
\hline Other Advanced & 0.015 & 0.015 & 0.019 & 0.024 & 0.026 & 0.031 & 0.044 & 0.058 & 0.069 & 0.065 & 0.070 & 0.070 & 0.061 \\
\hline Emerging and Developing Economies & 0.136 & 0.163 & 0.181 & 0.157 & 0.092 & 0.105 & 0.130 & 0.126 & 0.129 & 0.133 & 0.148 & 0.168 & 0.189 \\
\hline Developing Asia & 0.001 & 0.003 & 0.003 & 0.002 & 0.002 & 0.004 & 0.003 & 0.004 & 0.004 & 0.006 & 0.007 & 0.006 & 0.007 \\
\hline Europe & 0.754 & 0.887 & 0.913 & 0.779 & 0.513 & 0.584 & 0.725 & 0.647 & 0.616 & 0.641 & 0.699 & 0.760 & 0.782 \\
\hline Middle East and North Africa & 0.001 & 0.002 & 0.004 & 0.002 & 0.003 & 0.004 & 0.006 & 0.004 & 0.003 & 0.004 & 0.006 & 0.010 & 0.036 \\
\hline Sub-Saharan Africa & 0.006 & 0.001 & 0.010 & 0.002 & 0.001 & 0.001 & 0.005 & 0.004 & 0.023 & 0.009 & 0.014 & 0.022 & 0.017 \\
\hline Western Hemisphere & 0.004 & 0.003 & 0.007 & 0.008 & 0.006 & 0.005 & 0.002 & 0.006 & 0.002 & 0.007 & 0.008 & 0.008 & 0.010 \\
\hline
\end{tabular}

Sources: IMF, Direction of Trade Statistics; and IMF staff estimates. 